\title{
Martine Lavaud, Théophile Gautier militant du Romantisme
}

\section{Mario Richter}

\section{(2) OpenEdition}

1 Journals

\section{Edizione digitale}

URL: http://journals.openedition.org/studifrancesi/36502

DOI: 10.4000/studifrancesi.36502

ISSN: 2421-5856

\section{Editore}

Rosenberg \& Sellier

\section{Edizione cartacea}

Data di pubblicazione: 1 juillet 2005

Paginazione: 189

ISSN: 0039-2944

\section{Notizia bibliografica digitale}

Mario Richter, «Martine Lavaud, Théophile Gautier militant du Romantisme», Studi Francesi [Online], 145 (XLIX | I) | 2005, online dal 30 novembre 2015, consultato il 20 avril 2021. URL: http://

journals.openedition.org/studifrancesi/36502 ; DOI: https://doi.org/10.4000/studifrancesi.36502

Questo documento è stato generato automaticamente il 20 avril 2021.

\section{(c) $(1) \&$}

Studi Francesi è distribuita con Licenza Creative Commons Attribuzione - Non commerciale - Non opere derivate 4.0 Internazionale. 


\title{
Martine Lavaud, Théophile Gautier militant du Romantisme
}

\author{
Mario Richter
}




\section{NOTIZIA}

MARTINE LAVAUD, Théophile Gautier militant du Romantisme, Paris, Honoré Champion, 2001, pp. 638.

1 Le storie letterarie - incoraggiate da valutazioni di scrittori autorevoli come Flaubert e Zola - hanno fissato uno stereotipo che riduce Gautier alla duplice e contraddittoria funzione del militante romantico e antiborghese della battagtia romantica (il famoso «gilet rouge») e del successivo teorico dell'»art-pour l'art» degli Emaux et camées, imborghesito, rassegnato, ossequiente al Secondo Impero.

2 Riportando a una lettura attenta dell'opera sterminata di Gautier, questo libro ha la principale funzione di smontare in ogni sua parte uno schema solitamente accettato per arrivare a riconsegnare una diversa e ben più verosimile immagine dello scrittore. Ecco in quali termini l'A. ha esposto i criteri e i propositi fondamentali, ampiamente mantenuti, del suo articolato e preciso lavoro critico: “il ne peut y avoir d'approche réelle de Gautier qu'affranchie de la chronologie et des catégories, puisant librement dans la totalité de la création. Tout cloisonnement de son œuvre ne saurait être que précaire, tant les articles et les préfaces, les récits et la poésie, unis par la circulation très intime de l'esthétique qui les habite, demeurent entés les uns sur les autres. Il ne faut donc en écarter aucune partie a priori, tout en concevant l'impossibilité d'en parcourir la totalité. L'œuvre de Gautier, complexe mais pas impénétrable, fait circuler dans tous ses membres le sang de ce militantisme premier dont la mémoire ne s'est jamais perdue».

3 L'opera si impone per la non comune ricchezza di informazione, per la costante perspicacia critica che la guida e per l'innovativo, convincente valore delle sue argomentazioni e delle sue conclusioni. 